This is an electronic reprint of the original article. This reprint may differ from the original in pagination and typographic detail.

\author{
Author(s): livonen, Susanna; Sääkslahti, Arja; Mehtälä, Anette; Villberg, Jari; Soini, Anne; \\ Poskiparta, Marita
}

Title: $\quad$ Directly Observed Physical Activity and Fundamental Motor Skills in Four-Year-Old Children in Day Care

Year: $\quad 2016$

Version:

Please cite the original version:

livonen, S., Sääkslahti, A., Mehtälä, A., Villberg, J., Soini, A., \& Poskiparta, M. (2016). Directly Observed Physical Activity and Fundamental Motor Skills in Four-Year-Old Children in Day Care. European Early Childhood Education Research Journal, 24(3), 398-413. https://doi.org/10.1080/1350293X.2016.1164398

All material supplied via JYX is protected by copyright and other intellectual property rights, and duplication or sale of all or part of any of the repository collections is not permitted, except that material may be duplicated by you for your research use or educational purposes in electronic or print form. You must obtain permission for any other use. Electronic or print copies may not be offered, whether for sale or otherwise to anyone who is not an authorised user. 


\section{Directly Observed Physical Activity and Fundamental Motor Skills in Four-Year-Old Children in Day Care}

S. Iivonen ${ }^{\mathrm{a}}$, A.K. Sääkslahti ${ }^{\mathrm{a}}$, A. Mehtälä ${ }^{\mathrm{b}}$, J.J. Villberg ${ }^{\mathrm{b}}$, A. Soini ${ }^{\mathrm{c}}$ and M. Poskiparta $^{\mathrm{b}}$

${ }^{a}$ Department of Sport Sciences, University of Jyväskylä, Jyväskylä, Finland;

${ }^{b}$ Department of Health Sciences, University of Jyväskylä

${ }^{c}$ Department of Early Childhood Education, University of Jyväskylä

*S. Iivonen. E-mail: susanna.iivonen@jyu.fi. Postal address: Faculty of Sport and Health Sciences, Department of Sport Sciences, Viveca 289, Rautpohjankatu 8, FI40014 UNIVERSITY OF JYVÄSKYLÄ, Finland.

This work was carried out in Finland. 


\section{Directly Observed Physical Activity and Fundamental Motor Skills in}

\section{Four-Year-Old Children in Day Care}

Physical activity (PA), its location, social interactions and fundamental motor skills were investigated in four-year-old Finnish children in day care. Six skills in the stability, locomotor and manipulative domains were assessed in 53 children (24 boys, 29 girls, normal anthropometry) with the APM-Inventory manual for assessing children's perceptual and fundamental motor skills (Numminen, 1995) and Total Motor Scores (TMS; 0-6 points) calculated. PA intensity, location, group composition and activity type - sitting, squatting, kneeling - were directly observed with a modified version of the Observational System for Recording Physical Activity in Children-Preschool Version (OSRAC-P) (Brown et al. 2006) during three consecutive days in 14 centres. Altogether, 13302 PA intervals were analyzed. Results: Mean TMS was $2.45( \pm 1.8)$ points. Most PA intervals were coded as sedentary. Pearson Chi-squares indicated differences in PA intensities both between indoor and outdoor locations $(p<0.001)$ and between solitary and non-solitary group composition ( $p<0.018$ ). Indoors, more than $70 \%$ of intervals were spent sedentary and 5\% in moderate-to-vigorous PA (MVPA). Outdoors, sedentary accounted for $45 \%$ and MVPA $19 \%$. When solitary, 57\% of intervals were sedentary and 13\% MVPA. When non-solitary, $60 \%$ of intervals were sedentary and 12\% MVPA. $48 \%$ of intervals were spent sitting, squatting or kneeling. TMS were not significantly associated with biological factors, PA or social interaction, but outdoor PA tended toward statistical significance (IRR=1.88, $p=0.070$ ), indicating higher TMS in those who demonstrated more outdoor PA. We concluded that PA in day care may be inadequate to support children's fundamental motor skills development.

Keywords: fundamental motor skills; physical activity; direct observation; day care setting

\section{Activité physique et habiletés motrices fondamentales observées directement sur des enfants de quatre ans dans les garderies}


L'activité physique (PA), son contexte, les interactions sociales et les habiletés motrices fondamentales ont été étudiés sur des enfants finlandais de quatre ans dans les garderies. Six habiletés dans les domaines locomoteur, manipulatoire et d'équilibre ont été évaluées sur 53 enfants (24 garçons, 29 filles, anthropométrie normale) avec le manuel APM-Inventory pour l'évaluation des habiletés motrices fondamentales et perceptives des enfants (Numminen, 1995). Le Total Motor Score (TMS : 0-6 points) a été calculé. L'intensité PA, le contexte, la composition du groupe et le type d'activité (assise, accroupie, à genoux) ont été directement observés avec une version modifiée de l'OSRAC-P (Observational System for Recording Physical Activity in Children - Preschool Version) (Brown et al. 2006) pendant trois jours consécutifs dans 14 garderies. Un total de 13302 intervalles PA ont été analysés. Résultats : Le TMS moyen était de $2,45( \pm 1,8)$ points. La plupart des intervalles PA ont été identifiés comme sédentaires. Le khi-deux de Pearson a révélé des différences d'intensités PA entre les contextes intérieur et extérieur $(p<0,001)$ et entre la composition du groupe solitaire et non solitaire $(p<0,018)$. À l'intérieur, plus de $70 \%$ des intervalles étaient constitués d'activités sédentaires et $5 \%$ de PA d'intensité modérée à élevée (MVPA). À l'extérieur, les activités sédentaires s'élevaient à $45 \%$ et les MVPA à $19 \%$. En solitaire, $57 \%$ des intervalles étaient sédentaires et $13 \%$ étaient MVPA. En non solitaire, $60 \%$ des intervalles étaient sédentaires et $12 \%$ étaient MVPA. $48 \%$ des intervalles se déroulaient assis, accroupi ou à genoux. Les TMS n'étaient pas associés de façon significative aux facteurs biologiques, à la PA ou à l'interaction sociale. Cependant, la PA à l'extérieur s'est orientée vers une signification statistique ( $\mathrm{IRR}=1,88, p=0,070$ ) et a révélé un TMS plus élevé chez les enfants présentant davantage de PA à l'extérieur. Nous en concluons que la PA dans les garderies peut être insuffisante pour soutenir le développement des habiletés motrices fondamentales des enfants.

Mots-clés : habiletés motrices fondamentales, activité physique, observation directe, garderie

\section{Direkt beobachtete physische Aktivitäten und motorische Basisfähigkeiten vierjähriger Kinder im Kindergarten}

Die physische Aktivität (PA) und ihr Kontext sowie die sozialen Wechselbeziehungen und motorischen Basisfähigkeiten vierjähriger 
Kinder wurden in einem finnischen Kindergarten untersucht. Sechs

Fähigkeiten der Kategorien Gleichgewicht, Bewegung und Manipulation wurden bei 53 Kindern (24 Jungen, 29 Mädchen, normale

Anthropometrie) gemessen. Bei der Messung wurde das ,APM-Inventory“

(Numminen, 1995), ein Testhandbuch für die Evaluation von wahrnehmungsmotorischen und motorischen Basisfähigkeiten bei Vorschulkindern, benutzt. Die Total Motor Score (TMS; 0-6 Punkte) wurde auch errechnet. Die PA-Intensität, der Kontext, die Gruppenzusammensetzung und die Aktivitätsart - , sitzend ', ,kauernd oder ,kniend“ - wurden mit einer direkten, von der OSRAC-P (Observational System for Recording Physical Activity in Children Preschool Version) (Brown et al. 2006) adaptierten Beobachtungsmethode untersucht. Die Beobachtungen wurden an drei aufeinander folgenden Tagen in 14 Kindergärten verwirklicht. Insgesamt wurden 13.302 PAIntervalle analysiert. Ergebnisse: Der TMS-Durchschnitt lag bei 2.45 $( \pm 1.8)$ Punkten. Die meisten PA-Intervalle wurden in die Kategorie passiv (sitzend) kodiert. Der Pearsonsche Chi-Quadrat-Test hat Unterschiede in den PA-Intensitäten zwischen Innen- und Außenräumen bestätigt ( $p<0.001)$ sowie zwischen den Gruppenzusammensetzungen, allein` und ,nicht allein` $(p<0.018)$. Drinnen waren über $70 \%$ der Intervalle passiv und $5 \%$ enthielten PA, die von mäßig zu schwer (moderate-to-vigorous, MVPA) wechselte. Im Freien betrug der Anteil passiver Aktivität $45 \%$ und der Anteil der MVPA $19 \%$. Als die Kinder allein waren, waren $57 \%$ der Intervalle passiv und $13 \%$ enthielten MVPA. Als sie nicht allein waren, waren $60 \%$ der Intervalle passiv und $12 \%$ MVPA. Insgesamt 48 $\%$ der Intervalle wurden in die Kategorien ,sitzend', ,kauernd ' und ,kniend' kodiert. Es bestand kein signifikanter Zusammenhang zwischen der TMS und der PA, biologischen Faktoren oder sozialen Wechselbeziehungen. Die PA im Freien näherte sich jedoch der statistischen Signifikanz (IRR=1.88, $p=0.070$ ): Sie deutete auf eine bessere TMS bei Kindern, die mehr PA im Freien hatten. Wir haben schlussgefolgert, dass die PA im Kindergarten nicht unbedingt ausreichend die Entwicklung motorischer Basisfähigkeiten fördert. 
Schlüsselwörter: motorische Basisfähigkeiten; physische Aktivität; direkte Beobachtung; Kindergarten

\section{Observación directa de la actividad física y habilidades motoras fundamentales en niños de cuatro años en guardería}

La actividad física (AF), su lugar, las interacciones sociales y las habilidades motoras fundamentales fueron investigados en niños finlandeses de 4 años en la guardería. Seis habilidades en estabilidad, habilidades locomotoras y manipulativas fueron evaluadas en 53 niños (24 niños, 29 niñas, antropometría normal) con APM-Inventory Manual para evaluar las habilidades perceptuales y fundamentales motoras en niños (Numminen, 1995) y Total Motor Score (TMS; 0-6 puntos). La intensidad de la AF, el lugar, la composición del grupo y el tipo de actividad - 'sentados', 'en cuclillas', 'arrodillados' - fueron directamente observados con una versión modificada del Observational System for Recording Physical Activity in Children - Preschool Version (OSRAC-P) (Brown et al. 2006) durante 3 días consecutivos en 14 guarderías. En total, 13302 intervalos de actividad física fueron analizados. Resultados: la media TMS fue de $2.45( \pm 1.8)$ puntos. La mayoría de los intervalos de AF fueron clasificados como sedentarios. La prueba $\chi^{2}$ de Pearson indicó diferencias en la intensidad de la actividad física entre lugares cubiertos y al aire libre $(p<0.001)$ y entre grupos solitarios y no solitarios $(p<0.018)$. En lugares cubiertos, más del $70 \%$ de las actividades fueron sedentarias y un $5 \%$ en actividades de intensidad moderada a vigorosa (AFMV). Para actividades al aire libre, el $45 \%$ representaron los sedentarios y AFMV fue

de un $19 \%$. Estando solos, $57 \%$ de las actividades fueron sedentarias y un $13 \%$ 
AFMV. En grupos no solitarios un $60 \%$ de los intervalos fueron sedentarios y un $12 \%$ AFMV. $48 \%$ de los intervalos fueron de tipo 'sentados', 'en cuclillas' o 'arrodillados'. TMS no fue significativamente asociado con factores biológicos, AF o interacción social, pero las actividades físicas realizadas al aire libre tienden a ser estadísticamente significativas (IRR=1.88, $p=0.070$ ), indicando un TMS más alto en los que demostraron más AF al aire libre. Concluimos que la AF en la guardería puede ser inadecuada para apoyar el desarrollo de las habilidades motoras fundamentales.

Palabras clave: Habilidades motoras fundamentales, actividad física, observación directa, guardería

\section{Introduction}

Fundamental motor skills (FMS) play an important role in children's physical, cognitive, and social development (Gallahue and Donnelly 2003; Gallahue, Ozmun, and Goodway 2012). FMS comprise various stability (i.e. gaining control over musculature in opposition to gravity), locomotor (i.e. moving through space) and manipulative (i.e. making controlled contact with objects in one's environment) movements. Stability movements refer to static and dynamic balance skills such as standing on a one foot and walking on a straight line. Locomotor movements include running and hopping, and manipulative movements include skills such as throwing and kicking (Gallahue, Ozmun, and Goodway 2012). Children need FMS to survive everyday activities independently, learn more difficult skills, and engage in multiple physical activities (Gallahue and Donnelly 2003; Goodway 2009). Further, childhood FMS are associated with academic and health benefits in later life: children with more proficient FMS are more likely to adjust to normal schooling (Bart, Hajami, and Bar-Haim 2007), and to 
gain healthier weight status (Castetbon, and Andreyeva 2012), and higher cardiorespiratory fitness in later on in life (Barnett et al. 2008).

Early childhood is the period for FMS acquisition (Gallahue, Ozmun, and Goodway 2012). This developmental change is determined by many factors which may be classified into the subsystems of the child's biology (e.g. sex and neural maturation), of the movement task (e.g. an obstacle's height or the size of a goal), and the environmental context (e.g. indoor or outdoor surface, prompts to practise a skill, or playing solitary versus in a group of peers) (Gagen and Getchell 2006; Gallahue, Ozmun, and Goodway 2012; Newell 1986). Although children acquire rudimentary FMS as they grow and develop, to become mature these skills have to be practised, learned and reinforced (Goodway 2009). As the majority of young children are cared for in a centre-based setting (OECD Family database 2008), these contexts play a critical role in supporting children's FMS development and fostering their physical activity behaviours (Tremblay et al. 2012). It has been suggested that development of FMS per se should be a key component of early childhood physical education programs (Tremblay et al. 2012). It is recommended that children below five years of age are physically active for at least two hours per day, and caregivers minimize the children's sedentary time (e.g. prolonged sitting) (Active Healthy Kids Canada 2012; Australian Government Department of Health and Aging 2011; Department of Health 2011; Ministry of Social Affairs and Health 2005).

However, studies using objective physical activity measurements, such as direct observation or accelerometers, indicate that children in day care spend, in general, more than two-thirds of their waking time in sedentary activities and only approximately ten percent in MVPA (Bower et al. 2008; Brown et al. 2006; Nicaise, Kahan, and Sallis 2011). Further, many children may not develop mature forms of all major FMS (Okely 
and Booth 2004; Vandaele et al. 2011) and in young children some motor skills show a secular decline (Roth et al. 2010). These undesirable trends have been suggested to be partly due to education contexts that do not provide appropriate support and encouragement for skill-developing activities (Gagen and Getchell 2006; Okely and Booth 2004) and the general physical inactivity of present-day lifestyles (Roth et al. 2010). Over protective care giving, educators' perceptions, attitudes, and personal preferences as well as all time present technology, may also be responsible for placing children into environments which may restrict their opportunity to move vigorously and incorporate their skills to different challenges (Active Healthy Kids Canada 2012; Bundy et al. 2009; Copeland et al. 2012). Providing access to safe, open areas, either indoors or outdoors, where a child can move freely, and engage in vigorous play with equipment (e.g. ball) and toys may help to promote children's enjoyment in being physically active, trying new things, and developing their skills (Active Healthy Kids Canada 2012). Reducing time spent on teacher-centred education and permitting free play could be one way to reduce children's sedentary time (Brown et al. 2009).

The correlates of child care children's physical activity and sedentary behaviour have been widely investigated (Bower et al. 2008; Hinkley et al. 2010; Timmons et al. 2012). Motor skills proficiency (Bürgi et al. 2011; Fisher et al. 2005; Kambas et al. 2012) especially locomotor and manipulative skills (Cliff et al. 2009; Williams et al. 2008), have explained a significant amount of the variance in physical activity levels. It is recognized that FMS proficiency as such, and as a significant correlate of increased physical activity, is a critical health and development determinant. Despite this recognition, factors related to FMS proficiency have been less investigated (Lubans et al. 2010). Some studies have investigated associations between child-based factors (e.g. gender, age, habitual physical activity) and children's motor skills, but little research 
exists on contextual influences on children's FMS.

Only a few studies have explored relationships between environmental or family contextual factors and children's FMS proficiency. A Finnish study indicated a positive relationship between outdoor play, unattended play, and locomotor skills in three- to four-year-old children (Sääkslahti et al. 1999). A Norwegian study indicated that playing in the forest near the day care centre versus inside the center's perimeter fence positively affected children's balance and coordination (Fjørtoft 2001). Cools et al. (2011) found that parents' physical activity and high value placed on their child's sportspecific physical activity were positively associated with children's FMS performance (Cools et al. 2011). An Australian study indicated that although a number of family and environmental factors were positively associated with children's locomotor and manipulative skill proficiency, only child-level factors were significant (i.e. age, physical activity and less dance lessons participation) (Barnett et al. 2013).

This study examined four-year-old children's stability, locomotor and manipulative skill proficiency and directly observed physical activity intensity and its location and social interactions in the day care setting. The interest was in whether children's biological factors, physical activity and social interactions are associated with their FMS proficiency.

\section{Methods}

\subsection{Participants and setting}

Participants were randomly selected from 14 municipal day care centres that agreed to participate in a follow-up study targeted at day care children between the years 20102012. The initial target sample was 179 children born in 2007. The day care centres 
were situated in socioeconomically diverse districts in the same town (population approximately 130,000) in Central Finland. This study was conducted with 53 children ( 24 boys and 29 girls; mean age $4.07 \pm 0.32$ years). Data were collected from August to September 2011. In each centre, FMS, physical activity and anthropometry were assessed during the same week: FMS on Monday or Tuesday, physical activity from Wednesday to Friday, and anthropometry on Thursday or Friday. Mean daytime air temperature was $12.5^{\circ} \mathrm{C}$ and mean precipitation per month $128 \mathrm{~mm}$. The data collection was organized so as not to disturb the centres' daily routines. A written informed consent from a parent or guardian was obtained for each participating child, and the study approved by the Ethics Committee of the University of Jyväskylä.

\subsection{Anthropometry measures}

Children's height was measured to the nearest $0.1 \mathrm{~cm}$ using a portable Charder HM 200P stadiometer, and weight to the nearest $0.1 \mathrm{~kg}$ using a Seca 877 electronic scale. Body Mass Index (BMI) was calculated and expressed as $\mathrm{kg} / \mathrm{m}^{2}$.

\subsection{Measures of fundamental motor skills}

Six test items from the APM-Inventory manual and test booklet for assessing preschool children's perceptual and fundamental motor skills developed by Numminen (1995) for four- to-seven-year-old children were used. The test items fall into the domains of stability, locomotor and manipulative skills, which is important given the aim of gaining a full picture of overall motor proficiency at this age (Gallahue, Ozmun, and Goodway 2012). The intraclass correlations for test-retest reliability for children aged four to seven have ranged from 0.86-0.94 (Numminen, 1995).

The FMS measurements were carried out by the same two testers, who were trained by the authors. To render the measurement situation more comfortable, children 
were taken out of class for testing in groups of three, although each child was tested and scored individually. One of the testers gave each group a single demonstration of each test item followed by verbal instructions. The children were then asked to perform each test individually, while the other tester observed the performance and recorded the score (seconds, centimetres or points) on the child's personal test sheet. If a child felt uncomfortable in the test situation and refused to try a test item, he or she was not forced to perform that item. Consequently, scores for all six test items were not obtained for all the children (Table 2). Test duration for each group of three children was approximately 20 minutes. The testing was done in the preschool's own gymnasium.

Stability was assessed as static and dynamic balance. Static balance was the sum of balancing on the right and left foot $(1.0 \mathrm{~s}$; maximum 20 seconds per foot $\mathrm{x} 2=$ maximum 40 seconds). The child was asked to stand on each foot for as long as he or she could up to a maximum of 20 seconds. Where a child was able to stand on one foot longer than 20 seconds, he or she was asked to stop performing. Time was recorded with a stopwatch. Dynamic balance was total time taken ( 0.10 seconds) to jump sideways with both feet together 15 times over a platform $(25 \times 10 \mathrm{~cm})$ attached to the floor. The child was asked to jump as quickly as he or she could. Time was kept with a stopwatch, and jumps were counted out loud.

Locomotor skills were measured as the length $(1.0 \mathrm{~cm})$ of a standing broad jump and the sum score of sliding and galloping. In the standing broad jump test, a child was asked to jump as far as he or she could. Two trials were allowed, and the best taken as the result. Jump length was measured with a measurement tape. The sliding and galloping test comprised sliding sideways to the right and left and galloping. Performance was determined as presence or absence of performance, with two points scored if the child performed the movement and one point if not (max. six points). 
Manipulative skills were measured with two different tests. The throwing and catching combination comprised ten two-handed underarm soft ball (circumference 21 $\mathrm{cm}$ ) throws toward a wall from a distance of two meters, with two-handed catches after the ball had bounced on the floor once. Performance was determined as presence or absence of performance, with each successful catch scoring one point (max. ten points). Throws were counted out aloud. In throwing at a target, three tennis ball throws were executed with the preferred hand from a distance of two meters. The target comprised three concentric circles (20,40 and $60 \mathrm{~cm}$ in diameter). Hitting the innermost circle scored three points, the middle circle two points and the largest circle one point (max. nine points).

\subsection{Observation of physical activity, children's location and social interactions}

A modified version of the Observational System for Recording Physical Activity in Children-Preschool Version (OSRAC-P) (Brown et al. 2006) was used to measure children's physical activity intensity, location, and social interactions. Two trained researchers observed each child using a procedure in which 15 seconds of observation were followed by 30 seconds of recorded observation. This procedure was repeated eight times over six minutes per child. Each child was observed four times per day; twice in the morning (between 8 a.m. and 12 p.m., indoors and outdoors) and twice in the afternoon (between 2 p.m. and 5 p.m., indoors and outdoors) during three consecutive days. For statistical analysis, children were randomly selected for observation and not observed during scheduled meal or rest times. Data were collected without disturbing the daily routines of the childcare centres and without undue influence on the children or teachers.

Children's physical activity intensity levels were measured on a five-point scale $(1=$ stationary or motionless, $2=$ stationary with limb or trunk movements, $3=$ slow or 
easy movements, $4=$ moderate movements, and $5=$ fast movements) and reflected the highest intensity level reached by the child during each 15 -second observation interval. To enable inter-study comparisons, activity levels 1-2 were regarded as sedentary behaviour, activity level 3 as light physical activity and levels 4-5 as MVPA (Bower et al. 2008; Brown 2009; Nicaise, Kahan, and Sallis 2011; Pate et al. 2008). Children's sedentary behaviour was described by the Activity-type code "Sitting, squatting, kneeling”. In addition, two OSRAC-P scales were used to describe children's physical activity intensity levels: (1) Location (inside vs. outside the centre building) and (2) Group composition (solitary = engaging in a solitary activity and not in proximity to peers or adults vs. one-to-one adult or one-to-one peer or group adult or group child). .

\subsection{Statistical Analysis}

Statistical analysis was performed using IBM SPSS Statistics 20 (IBM Corporation, New York) and STATA software, version 13 (Stata, College Station, TX). Children's FMS proficiency was determined as follows. Distributions of the scores of each of the six FMS tests were explored and cumulative percentages examined to determine the cut-point scores for higher and lower proficiency. The cut-points were used to recode the FMS variables as dichotomous variables, with zero points indicating lower proficiency and one point higher proficiency. The cut-point scores of the FMS variables for higher proficiency and percentages of children with this level of proficiency are shown in Table 2. The dichotomized scores of the six FMS tests were then summed to form a total motor skill score with a minimum score of zero points and maximum score of six points. Hence, a sum score of zero points indicated the lowest proficiency level, and a sum score of six points the highest proficiency level. To describe the study population and their scores for the different FMS and total motor skill score, means and 
standard deviations for age in months, height, weight, BMI and the FMS variables were calculated for the whole sample and for boys and girls separately.

The OSRAC-P scores of both observers for the dichotomous variable group composition solitary vs. other (yes/no) was combined by coding the variable as present (1) when rated by one or both observers as present, and coding it as absent (0) when both rated it as absent. For continuous variables (i.e. activity intensity), the mean of the scores of both observers was calculated. Cohen's kappa was used to determine interrater reliability (IRR) during the observations of the OSRAC-P variables (i.e. activity intensity, location, group composition, and activity type sit, squat, kneel). IRRs ranged between 0.62 and0.97 $(\mathrm{SE}=0.003-0.011 ; \mathrm{p}<0.001)$. Number of observed OSRAC-P intervals was totalled and crosstabs run to calculate the numbers of intervals and percentages of total intervals in the different physical activity intensity levels by location (i.e. inside and outside) and group composition (i.e. solitary and non-solitary). Pearson chi-square tests were used to investigate whether the intervals observed in different physical activity intensity levels differed by location and by group composition.

Finally, to analyse the associations between children's biological factors, their directly observed physical activity, group composition, activity type sitting, squatting, kneeling and FMS proficiency, we employed Poisson regression in terms of incidence rate ratios (IRR). IRR is defined here as a change in in the total motor skill score that was predicted by a one-unit change in the predictor variable, holding the other variables in the model constant. For example, if a child was to increase his or her outside physical activity intensity intervals by one unit, his or her rate ratio for total motor skill score could be expected to increase (IRR > 1.0) or decrease (IRR < 1.0) by a value of 
IRR, while holding all the other variables in the model constant. In all analyses, $P$ values $<0.05$ were considered statistically significant.

\section{Results}

The weight, height and body mass index of the 53 children are presented in Table 1 and corresponded to the age group norms for Finnish children (Saari et al. 2011). Motor skills assessments were obtained for 37 to 53 children. Not all children completed all the tasks. Means, standard deviations, and the higher proficiency cut-point scores for the six measured FMS are presented in Table 2. One-foot static balance was performed by 37 children, of whom $50 \%$ held the position for more than 10 out of the maximum of 40 seconds. Girls were static for 10 seconds longer than boys. In the dynamic balance test, $49.5 \%$ of the 50 children performed 15 jumps sideways in less than 20 seconds.

The standing broad jump was performed by all the children, with $51.5 \%$ able to jump longer than $71 \mathrm{~cm}$. Of the 37 children who performed the sliding and galloping test, $52.8 \%$ scored four or more of the maximum of six points. Of the 49 children who tried the throwing and catching combination 10 times, $32.3 \%$ were managed at least one successful performance.

The children's mean total skill score (0-6 points), calculated based on the cutpoint scores of the six FMS tests, was $2.45( \pm 1.8)$ points. Boys scored $2.45( \pm 1.77)$ and girls $2.44( \pm 1.86)$ points.

INSERT Table 1 HERE (Table 1. Demographic information for total sample and by gender.)

INSERT Table 2 HERE (Table 2. Means (M) and standard deviations (SD) of the scores for fundamental motor skills and cut-point scores for higher proficiency level.) 
Altogether, 13302 intervals of physical activity data were analyzed (Table 3) of which 6855 intervals were indoors and 6447 outdoors. Statistically significant differences emerged between indoors and outdoors in the intervals observed at the different physical activity intensity levels $(\chi 2(2)=1184.18, p<0.001)$. Indoors, more than $70 \%$ of intervals were sedentary and approximately 5\% of intervals MVPA. Outdoors, the percentages of MVPA were approximately $23 \%$ in boys and $15 \%$ in girls. Outdoors, approximately $45 \%$ of intervals were sedentary. The percentage of intervals spent sitting, squatting or kneeling was $47.9 \%$ (46.8\% in boys and $49.4 \%$ in girls).

Statistically significant differences also emerged between solitary and nonsolitary group composition at the different physical activity intensity levels $\left(\chi^{2}(2)=\right.$ $8.005, p<0.018)$. When solitary, $57 \%$ of intervals were sedentary and approximately $13 \%$ MVPA. When non-solitary, the prevalence of sedentary behaviour was even higher, at approximately $60 \%$. The prevalence of different physical activity intensity levels when solitary was the same for both genders. When non-solitary, children spent approximately $12 \%$ of intervals in MVPA. When non-solitary, boys spent approximately $14 \%$ and girls $9 \%$ of intervals in MVPA.

INSERT Table 3 HERE (Table 3. Number (count) and percentage (\%) of total ( $\mathrm{N}=13$ 302) physical activity intensity intervals by location and group composition.)

In a multivariate model, the biological, physical activity and group composition determinants were not significantly associated with the total motor skill score (0-6 points; Table 4). In the model, only outside physical activity intensity showed a trend toward statistical significance $(\mathrm{IRR}=1.88 ; 95 \% \mathrm{CI}=0.95,3.74 ; p=0.070)$, indicating 
that the incidence of higher scores in total motor skill was higher in those who demonstrated more outdoor physical activity intervals.

INSERT Table 4 HERE: (Table 4. Incidence rate ratios (ICC) of total motor skill score (0-6 points) and 95\% confidence interval (95\% CI) by determinants assessed using Poisson regression.)

\section{Discussion}

In this study, FMS proficiency was measured and physical activity, its location and social interactions directly observed in four-year-old Finnish children in the day care setting. The children scored less than three out of six points in the total score describing their FMS proficiency in six motor skills in the stability, locomotor and manipulative domains. The children's physical activity intensity, both indoors and outdoors and both when solitary and non-solitary was mostly sedentary in nature. No statistically significant relationship was found between the incidence of better total FMS scores and the children's biological factors, physical activity or social interactions.

\subsection{Relationships between motor skills and activity}

Of the children's biological factors, physical activity intervals and social interactions, only having more outdoor physical activity intervals showed a trend toward a statistically significant relationship with the incidence of a higher total motor skill score. This might suggest that, outdoors, children tend to engage in physical activities that support their gross motor skill development. This speculation is supported by earlier studies indicating that time spent outdoors is associated with a higher amount of 
physical activity (Klesges et al. 1990), and a positive relationship between high level of play activities and gross motor skills (Sääkslahti et al. 1999). Earlier studies using different measures than ours have indicated weak and conflicting directions in the relationships between FMS and MVPA intensity in this age group (Cliff et al. 2009; Fisher et al. 2005; Williams et al. 2008). For instance, Fisher et al. (2005) reported low but significant correlations between MVPA and total motor skill score in young Scottish children, whereas Cliff and colleagues (2009) found an inverse relationship between physical activity and locomotor skills in young Australian girls and a positive relationship between physical activity and manipulative skills in boys. Another recent study in Australia indicated that among the several child-based factors, family physical activity circumstances and environmental characteristics studied, only children's age, MVPA and less participation in dance lessons explained a significant amount of the variance of their locomotor or manipulative skill proficiency (Barnett et al. 2013).

\subsection{Relationships' complexity}

The diverse results obtained on the relationships between motor skills and their determinants, including physical activity, reflect the fact these relationships are complex, as proposed in the motor skill development model of Gallahue et al. (2012): motor skills in children are associated with individual, task and environment level factors and thus dynamic. The evidence of this and previous studies suggests that physical activity may be a critical determinant of FMS in day care-aged children (Barnett et al. 2013; Fisher et al. 2005; Iivonen and Sääkslahti 2013). In light of the research evidence, we suggest that spending a lot of time outdoors, allowing adequate amounts of active free play (Sääkslahti et al. 1999), providing access to diversified physical environments (Fjørtoft 2001) and raising parental awareness of the importance of physical activity for their child (Barnett et al. 2013; Cools et al. 2011) are among the 
important factors to be considered when designing motor skill-promoting strategies in the day care setting. We also think that education in the importance of motor skill development for children's wellbeing and overall development and knowledge of the circumstances that facilitate physical activity should be important part of early childhood education programs (Tremblay et al. 2012).

\subsection{Variance in proficiency}

Six fundamental motor skills in the stability, locomotor and manipulative domains were measured, and means and cut-point scores for more skilled and less skilled performances were determined. As expected, children's proficiency varied across these skills. Results indicated that girls maintained static balance for ten seconds longer than boys, whereas boys scored higher than girls in both the manipulative skill tests. These gender differences were expected (Thomas and French 1985). Gender differences in FMS at a young age are more influenced by environmental than biological factors.

Overall, our FMS results are in line with those of earlier Finnish studies that have used the same test-battery but also younger or older age groups of children than in this study (Iivonen, Sääkslahti, and Nissinen 2011; Sääkslahti et al. 1999). Approximately $70 \%$ of the present children scored zero points in the throwing and catching combination test. There are several possible reasons for this. The throwing and catching test used in this study is a demanding task where children have to combine stability, locomotor and manipulative movements using their perceptual motor processes. It is reasonable to assume that many of these FMS were still emerging in these four-year-olds, and thus their motor skill repertoire was too limited for this test. It is also possible, that the children have not received instruction and adequate opportunities to practise these kinds of manipulative skills. Earlier studies have 
indicated that an adequate practice environment during early childhood is necessary to acquire proficiency in throwing and catching (Zask et al. 2012). Finnish early childhood physical activity guidelines for promoting FMS in different settings and environments are provided to early educators (Ministry of Social Affairs and Health 2005), and thus it can be assumed that the teachers had access to adequate written information on motor skill promotion.

\subsection{Limiting environmental factors}

However, in light of the present results, it can be argued that the day care environment may have limited children's opportunities to acquire gross motor skills. More than $70 \%$ of the observed activity behaviours were classified as sedentary. This indicates a considerable amount of stationary or motionless activity without big limb movements. Almost $50 \%$ of the observation intervals were coded as sitting, squatting or kneeling. These findings resemble those of earlier observational studies in day care-aged children (Bower et al. 2008; Brown 2009; Nicaise, Kahan, and Sallis 2011). We also found that children's activity levels differed between indoors and outdoors and whether a child was solitary or not.

As expected, (Brown 2009; van Cauwenberghe 2012), children's physical activity intensity was higher outdoors than indoors. The proportion (almost $20 \%$ of total intervals) of MVPA outdoors is in accordance with Nicaise, Kahan, and Sallis (2011). Although they found that many playground attributes such as large open spaces or activity-stimulating equipment enhanced children's MVPA, the effects of these attributes on children's activity levels were highly dependent on the specific day care context (Nicaise, Kahan, and Sallis 2011).

Further, it has been indicated that simply increasing outdoor time might not be 
enough to increase physical activity levels (Alhassan, Sirard, and Robinson 2007);

instead, structured activities might be needed to increase MVPA (van Cauwenberghe et al. 2012). However, understanding of the complexity of the impact of environmental circumstances on children's physical activity behaviour is limited. A recent study on the effects of different day care playgrounds on children's activity levels indicated little environmental impact; rather the activity levels differed on an individual basis (Storli 2010). However, the authors raised the important point that although environment affordances may have little impact on cardio- metabolic physical activity, they may be important for qualitative interpretations of skill and economy of movement (Storli 2010). We recommend that future studies more extensively explore what types of activities and facilities in the day care context should be targeted to foster children's vigorous physical activity behaviours and gross motor skill development. This is warranted, as a recent national report on the physical activity facilities of Finnish day care centres indicated that the majority lack the space and equipment required for diversified physical activities (Ruokonen, Norra and Karvinen 2009).

\subsection{Sedentariness}

An alarming finding of this study was that, while indoors, children engaged in MVPA for only approximately $5 \%$ and in sedentary behaviour for $73 \%$, of the observed intervals. Reasons for these low activity levels are not well understood. A recent study from the Netherlands suggested that children's indoor activity levels tended to be lower when certain toys and equipment were present, and when there was limited space to move around (Gubbels et al. 2011). Children are reportedly more physically active when more space is available (Gubbels et al. 2011; Nicaise, Kahan, and Sallis 2011). We found that children's physical activity intensity was higher when they were solitary and not in proximity to peer(s) or adult(s). This might indicate that, when solitary, the 
children had more space for vigorous movement and were able to use activitystimulating toys and equipment without needing to share them with others. Earlier studies have indicated that solitary play is strongly associated with MVPA (Brown et al. 2009; Nicaise, Kahan, and Sallis 2011).

Other possible reasons for the present children's low activity levels could be that day care staff's preferences and decisions were not physical activity-oriented, and hence they did not tend to encourage children's physical activity (Brown 2009; Copeland et al. 2012) or had limited competence in physical education (Bower et al. 2008). For example, in Finland the amount of physical education studies on early childhood teacher education has regrettably decreased in the twentieth century (Iivonen 2008). It is important to recognize that physical activity and sedentary behaviours begin in early childhood, and have been shown to track from this period into adolescence and adulthood (Malina 1996). This justifies targeting young children. Knowing that physical activity levels decline as children get older, beginning at age four, it is crucial to target the day care age group in seeking to limit this reduction (Goldfield et al. 2012; Taylor et al. 1999).

\subsection{Strengths and limitations}

This study has its strengths and limitations. To our knowledge, this was the first study to use direct physical activity observation in the day care setting and address whether observed physical activity and biological factors were associated with children's success in six FMS tests. The participants comprised 53 children with typical anthropometry, of whom more than half $(n=29 ; 55 \%)$ were girls. Including children's body size data and age in months in the multivariate model allowed us to control for biological factors to examine the unique variance in the total motor skill score explained 
by physical activity and contextual factors. We used an age-appropriate measure of FMS that encompassed all three domains of fundamental motor skills (Gallahue and Donnelly 2003) and determined a composite that described the children's FMS proficiency level on a six-point scale. The FMS measurement used here was productoriented, and thus may be considered an objective measure because it is not dependent on observers' skills. However, the use of a product-oriented rather than process-oriented measure of FMS can be viewed as a weakness. Researchers have stated that at beginning levels of FMS, such as the early childhood years, products (e.g. centimeters and seconds) of performances are inconsistent and low, and thus may not sufficiently differentiate between individuals (Cliff et al. 2009). A process-oriented assessment conducted by analyzing movement has been regarded as a more appropriate approach in young children (Cliff et al. 2009). The use of direct physical activity observation, rather than self-report, is, however, a strength of this study. The observation was performed by two observers who showed good inter-observer agreement. Although the length of the observation period (15 seconds) was based on the design of a previous study using the same method (Gubbels et al. 2011), a different period could have influenced the results. Moreover, total observation time is arguably not representative of a child's physical activity throughout the day care day. However, the observations were conducted in each centre in both the morning and afternoon, which covers the typical Finnish day care day. We wanted to conduct all measurements and observations so as to minimize the disruption to the children's and centres' daily routines. Finally, children's behaviour could have been affected by other variables not included in this study. For example, different physical activity locations have previously been linked to children's activity levels (e.g. Nicaise, Kahan, and Sallis 2011) but were not included here. The number of observed intervals in the different physical activity type categories or specific indoor 
and outdoor location categories was limited in our analysis, and we were not able to define different physical activity types or specific activity locations indoors and outdoors in our study.

\section{Summary bullets}

- Four-year-old day care children showed varied proficiency in fundamental motor skills in the stability, locomotor and manipulative domains. The majority of the children were unable to perform a successful throwing and catching combination.

- Children's directly observed physical activity in day care setting was mostly sedentary. Almost half of all observation units were spent sitting, squatting or kneeling. Statistically significant differences emerged in physical activity levels between indoor and outdoor locations and between solitary and non-solitary group composition. Indoors, children spent more of the total units in sedentary behaviour. MVPA was higher outdoors. Children were more active when solitary than in a group of peer(s) or adult(s).

- Of the children's biological and physical activity contextual variables, only outdoor physical activity units tended toward a statistically significant relationship to total motor skill proficiency. This indicates that children who demonstrated more physical activity outdoors tended to score higher in the six measured skills.

- Future studies should more extensively explore activities and facilities in the day care centre context that foster children's vigorous physical activity behaviours and gross motor skill development. Future studies should also include investigation of factors on the educatorlevel . 
Acknowledgements

We wish to thank the day care centers, children and their parents for their participation, and the research assistants of the Department of Health Sciences for their help with the data collection. This study was funded by the Ministry of Social Affairs and Health, and Ministry of Education and Culture, Finland.

\section{References}

Active Healthy Kids Canada. 2012. Is active play extinct? The Active Healthy Kids Canada 2012 report card on physical activity for children and youth. Toronto: Active Healthy Kids Canada.

Alhassan, S., J. Sirard, and T. N. Robinson. 2007. "The Effects of Increasing Outdoor Play Time on Physical Activity in Latino Preschool Children." International Journal of Pediatric Obesity 2 (3): 153-158.

Australian Goverment. Department of Health and Aging. 2011. Move and Play Every Day. National Physical Activity Recommendations for Children 0-5 Years. Commonwealth of Australia. Department of Health and Ageing.

Barnett, L., T. Hinkley, A. D. Okely, and J. Salmon. 2013. "Child, Family and Environmental Correlates of Children's Motor Skill Proficiency." Journal of Science and Medicine in Sport 16 (4): 332-336.

Barnett, L. M., E. van Beurden, P. J. Morgan, L. O. Brooks, and J. R. Beard. 2008. "Does Childhood Motor Skill Proficiency Predict Adolescent Fitness?" Medicine \& Science in Sports \& Exercise 40 (12): 2137-2144.

Bart, O., D. Hajami, and Y. Bar-Haim. 2007. "Predicting School Adjustment from Motor Abilities in Kindergarten." Infant and Child Development 16 (6): 597-615.

Bower, J. K., D. P. Hales, D. F. Tate, D. A. Rubin, S. E. Benjamin, and D. S. Ward. 2008. "The Childcare Environment and Children's Physical Activity." American Journal of Preventive Medicine 34 (1): 23-29.

Brown, W. H. 2009. "Effects of Teacher-Encouraged Physical Activity on Preschool Playgrounds." Journal of Early Intervention 31 (2): 126-145.

Brown, W. H., K. A. Pfeiffer, K. L. McIver, M. Dowda, C. L. Addy, and R. R. Pate. 2009. "Social and Environmental Factors Associated with Preschoolers? Nonsedentary Physical Activity." Child Development 80 (1): 45-58. 
Brown, W. H., K. A. Pfeiffer, K. L. McIver, M. Dowda, and et al. 2006. "Assessing Preschool Children's Physical Activity: The Observational System for Recording Physical Activity in Children-Preschool Version." Research Quarterly for Exercise and Sport 77 (2): 167-176.

Bundy, A. C., T. Luckett, P. J. Tranter, G. A. Naughton, S. R. Wyver, J. Ragen, and G. Spies. 2009. "The Risk is that there is 'no Risk': A Simple, Innovative Intervention to Increase Children's Activity Levels." International Journal of Early Years Education 17 (1): 33-45.

Castetbon, K. and T. Andreyeva. 2012. "Obesity and Motor Skills among 4- to 6-YearOld Children in the United States: Nationally-Representative Surveys." BMC Pediatrics 1: 28. http://www.biomedcentral.com/1471-2431/12/28.

van Cauwenberghe, E., V. Labarque, J. Gubbels, I. De Bourdeaudhuij, and G. Cardon. 2012. "Preschooler's Physical Activity Levels and Associations with Lesson Context, Teacher's Behavior, and Environment during Preschool Physical Education." Early Childhood Research Quarterly 27 (2): 221-230.

Cliff, D. P., A. D. Okely, L. M. Smith, and K. McKeen. 2009. "Relationships between Fundamental Movement Skills and Objectively Measured Physical Activity in Preschool Children." Pediatric Exercise Science 21 (4): 436-449.

Cools, W., K. De Martelaer, C. Samaey, and C. Andries. 2011. "Fundamental Movement Skill Performance of Preschool Children in Relation to Family Context." Journal of Sports Sciences 29 (7): 649-660.

Copeland, K. A., C. A. Kendeigh, B. E. Saelens, H. J. Kalkwarf, and S. N. Sherman. 2012. "Physical Activity in Child-Care Centers: Do Teachers Hold the Key to the Playground?" Health Education Research 27 (1): 81-100.

Department of Health. 2011. Physical activity guidelines for early years (under 5s) - for children who are capable of walking.

https://www.gov.uk/government/uploads/system/uploads/attachment_data/file/213 738/dh_128143.pdf.

Fisher, A., J. J. Reilly, L. A. Kelly, C. Montgomery, A. Williamson, J. Y. Paton, and S. Grant. 2005. "Fundamental Movement Skills and Habitual Physical Activity in Young Children." Medicine \& Science in Sports \& Exercise 37 (4): 684-688.

Fjørtoft, I.. 2001. "The Natural Environment as a Playground for Children: The Impact of Outdoor Play Activities in Pre-Primary School Children." Early Childhood Education Journal 29 (2): 111-117.

Gagen, L. M. and N. Getchell. 2006. "Using "Constraints" to Design Developmentally Appropriate Movement Activities for Early Childhood Education." Early Childhood Education Journal 34 (3): 227-232.

Gallahue, D. L. and F. Cleland Donnelly. 2003. Developmental Physical Education for all Children. 4th Edition. Champaign, IL: Human Kinetics. 
Gallahue, D. L., J. C. Ozmun, and J. Goodway. 2012. Understanding Motor Development: Infants, Children, Adolescents, Adults. 7th ed. New York: McGrawHill.

Goldfield, G. S., A. Harvey, K. Grattan and K. B. Adamo. 2012. "Physical Activity Promotion in the Preschool Years: A Critical Period to Intervene." International Journal of Environmental Research and Public Health 9 (4): 1326-1342.

Goodway, J. D. 2009. "What's Skill Got to do with it?: A Developmental Approach to Promoting Physical Activity in Urban Youths." Journal of Physical Education, Recreation \& Dance 80 (8): 38-40.

Gubbels, J. S., S. P.J. Kremers, D. H.H. van Kann, A. Stafleu and et al. 2011. "Interaction between Physical Environment, Social Environment, and Child Characteristics in Determining Physical Activity at Child Care." Health Psychology, 30 (1): 84-90.

Hinkley, Trina, Jo Salmon, Anthony D. Okely, and Stewart G. Trost. 2010. "Correlates of Sedentary Behaviours in Preschool Children: A Review." International Journal of Behavioral Nutrition and Physical Activity 7 (Sep 8): 66-66.

Iivonen, Susanna and Arja. K. Sääkslahti. 2013. "Preschool Children's Fundamental Motor Skills: A Review of Significant Determinants." Early Child Development and Care: 1-20. DOI:10.1080/03004430.2013.837897.

Iivonen, Susanna, Arja Sääkslahti, and Kari Nissinen. 2011. "The Development of Fundamental Motor Skills of Four- to Five-Year-Old Preschool Children and the Effects of a Preschool Physical Education Curriculum." Early Child Development and Care 181 (3): 335-343.

Iivonen, Susanna. 2008. "Early Steps -Liikuntaohjelman Yhteydet 4-5-Vuotiaiden Päiväkotilasten Motoristen Perustaitojen Kehitykseen." ["The Associations between an Early Steps Physical Education Curriculum and the Fundamental Motor Skills Development of 4- to 5-year-old Preschool Children"] PhD diss., University of Jyväskylä.

Klesges, Robert C., Linda H. Eck, Cindy L. Hanson, Keith C. Haddock, and Lisa M. Klesges. 1990. "Effects of Obesity, Social Interactions, and Physical Environment on Physical Activity in Preschoolers." Health Psychology 9 (4): 435-449.

Lubans, David R., Philip J. Morgan, Dylan P. Cliff, Lisa M. Barnett, and Anthony D. Okely. 2010. "Fundamental Movement Skills in Children and Adolescents." Sports Medicine 40 (12): 1019-1035.

Malina, Robert M. 1996. "Tracking of Physical Activity and Physical Fitness across the Lifespan." Research Quarterly for Exercise and Sport 67 (3): S48.

Ministry of Social Affairs and Health. 2005. Recommendations for Physical Activity in Early Childhood Education. Helsinki: Brochures of the Ministry of Social Affairs and Health 2005, 17. 
Newell, K. M. 1986. "Constraints on the Development of Coordination." In Motor

Development in Children: Aspects of Coordination and Control., edited by M. G. Wade and H. T. A. Whiting. Dordrecht: Nijhoff. 341-360.

Nicaise, Virginie, David Kahan, and James F. Sallis. 2011. "Correlates of Moderate-toVigorous Physical Activity among Preschoolers during Unstructured Outdoor Play Periods." Preventive Medicine 53 (4-5): 309-315.

Numminen, Pirkko. 1995. "Alle Kouluikäisten Lasten Havaintomotorisia ja Motorisia Perustaitoja Mittaavan APM-Testistön Käsikirja” ["APM-Inventory. Manual Test Booklet for Assessing Preschool Children's Perceptual and Fundamental Motor Skills"]. Jyväskylä, Finland: LIKES.

OECD Family Database 2008. Last updated June 2011. http://www.oecd.org/els/social/family/ database.

Okely, Anthony D. and Michael L. Booth. 2004. "Mastery of Fundamental Movement Skills among Children in New South Wales: Prevalence and Sociodemographic Distribution." Journal of Science \& Medicine in Sport 7 (3): 358-372.

Pate, Russell R., Kerry McIver, Marsha Dowda, William H. Brown, and Cheryl Addy. 2008. "Directly Observed Physical Activity Levels in Preschool Children." Journal of School Health 78 (8): 438-444.

Roth, Kristine., Katharina, C. Ruf, Mathias Obinger, Sonja Mauer, Jutta Ahnert, Wolfgang Schneider, Christine Graf, and Helge Hebestreit. 2010. "Is there a Secular Decline in Motor Skills in Preschool Children?" Scandinavian Journal of Medicine \& Science in Sports 20 (4): 670-678.

Ruokonen, Reijo, Jan Norra and Hanna Karvinen. 2009. Valtakunnallinen Selvitys Päiväkotien Liikuntaolosuhteista. [National Report of Day Care Centers' Physical activity Facilities]. Helsinki: Young Finland.

http://www.nuorisuomi.fi/files/lahiliikuntapaikat/Liitetiedostot/Paivakotiselvitys_n ettilaatu.pdf.

Sääkslahti, Arja, Pirkko Numminen, Harri Niinikoski, Leena Rask-Nissila, Jorma Viikari, Juhani Tuominen, and Ilkka Välimäki. 1999. "Is Physical Activity Related to Body Size, Fundamental Motor Skills, and CHD Risk Factors in Early Childhood?" Pediatric Exercise Science 11 (4): 327-340.

Saari, Antti, Ulla Sankilampi, Marja-Leena Hannila, Vesa Kiviniemi, Katja Kesseli and Leo Dunkel. 2011. "New Finnish Growth References for Children and Adolescents Aged 0 to 20 Years: Length/Height-for-Age, Weight-for-Length/Height, and Body Mass Index-for-Age." Ann Med 43 (3): 235-248.

Storli, Rune and Hagen, Trond. 2010. "Affordances in Outdoor Environments and Children's Physically Active Play in Pre-School." European Early Childhood Education Research Journal (4): 445. 
Taylor, Wendell C., Steven N. Blair, Sharon S. Cummings, Chuan Chuan Wun, and Robert M. Malina. 1999. "Childhood and Adolescent Physical Activity Patterns and Adult Physical Activity." Medicine \& Science in Sports \& Exercise 31 (1): 118-123.

Thomas, Jerry R. and Karen E. French. 1985. "Gender Differences across Age in Motor Performance: A Meta-Analysis." Psychological Bulletin 98 (2): 260-282.

Timmons, Brian W., Allana G. LeBlanc, Valerie Carson, Sarah Connor Gorber, Carrie Dillman, Ian Janssen, Michelle E. Kho, and et al. 2012. "Systematic Review of Physical Activity and Health in the Early Years (Aged 0-4 Years)." Applied Physiology, Nutrition \& Metabolism 37 (4): 773-792.

Tremblay, Line, Céline Boudreau-Larivière, Krystel Cimon-Lambert. 2012. "Promoting Physical Activity in Preschoolers: A Review of the Guidelines, Barriers, and Facilitators for Implementation of Policies and Practices." Canadian Psychology 53 (4): $280-290$.

Vandaele, Bart, Wouter Cools, Steve de Decker, and Kristine de Martelaer. 2011. "Mastery of Fundamental Movement Skills among 6-Year-Old Flemish Pre-School Children." European Physical Education Review 17 (1): 3-17.

Williams, Harriet G., Karin A. Pfeiffer, Jennifer R. O'Neill, Marsha Dowda, Kerry L. McIver, William H. Brown, and Russell R. Pate. 2008. "Motor Skill Performance and Physical Activity in Preschool Children." Obesity 16 (6): 1421-1426.

Zask, Avigdor, Lisa M. Barnett, Lauren Rose, Lyndon O. Brooks, Maxine Molyneux, Denise Hughes, Jillian Adams, and Jo Salmon. 2012. "Three Year Follow-Up of an Early Childhood Intervention: Is Movement Skill Sustained?" International Journal of Behavioral Nutrition and Physical Activity. 9 (1): 663. http://www.ijbnpa.org/content/9/1/127. 
Table 1. Demographic information for total sample and by gender.

\begin{tabular}{lllllll}
\hline & Total $(\mathbf{N}=\mathbf{5 3})$ & \multicolumn{2}{c}{ Boys $(\mathbf{N}=\mathbf{2 4})$} & \multicolumn{2}{c}{ Girls (N = 29) } \\
& $\boldsymbol{M}$ & $(\mathrm{SD})$ & $\boldsymbol{M}$ & $\boldsymbol{S D}$ & $\boldsymbol{M}$ & $\boldsymbol{S D}$ \\
\hline Age (months) & 48.89 & $(3.81)$ & 49.54 & $(4.08)$ & 48.34 & $(3.56)$ \\
Height (cm) & 103.60 & $(5.34)$ & 104.38 & $(6.74)$ & 102.97 & $(3.84)$ \\
Weight (kg) & 17.36 & $(2.52)$ & 17.54 & $(2.78)$ & 17.22 & $(2.32)$ \\
BMI (kg/m2) & 16.17 & $(1.39)$ & 16.07 & $(1.22)$ & 16.25 & $(1.53)$ \\
\hline
\end{tabular}

Note: $M=$ Mean; $S D=$ Standard Deviation. 
Table 2. Means (M) and standard deviations (SD) of the scores for fundamental motor skills and cut-point scores for higher proficiency level.

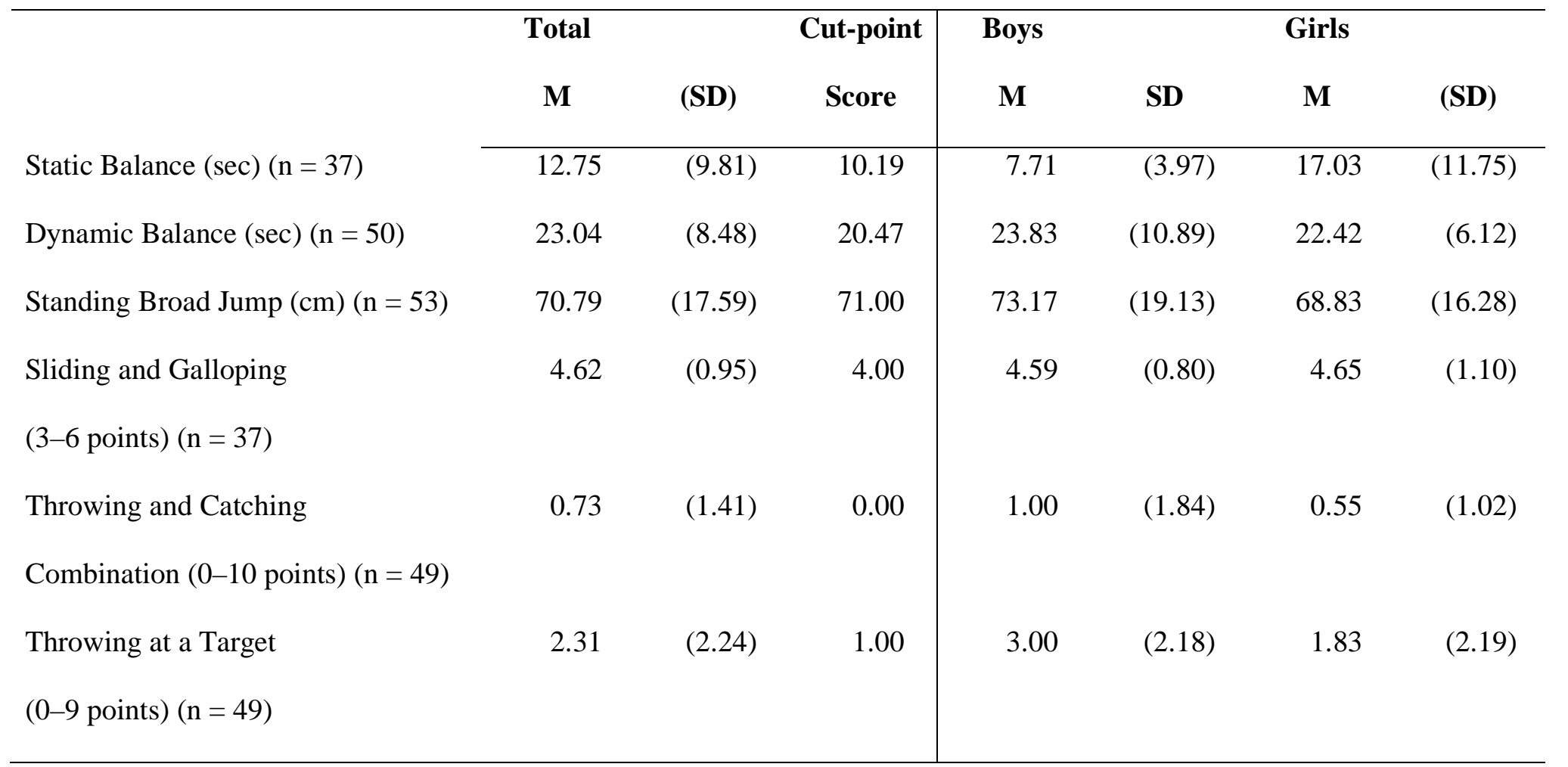

Note: $\mathrm{n}=$ number of participants who performed the test item; $50 \%$ of children scored higher than the cut-point score for static balance; $49.5 \%$ of children scored higher than the cut-point score for dynamic balance; $51.5 \%$ of children scored higher than the cut-point score for standing broad jump; $52.8 \%$ of children scored higher than the cut-point score for sliding and galloping; $32.3 \%$ of children scored higher than zero points in throwing and catching combination; $54.2 \%$ of children scored higher than 1 point in throwing at a target. 
Table 3. Number (count) and percentage $(\%)$ of total $(\mathrm{N}=13302)$ physical activity intensity intervals by location and group composition.

\begin{tabular}{|c|c|c|c|c|c|c|c|c|c|c|c|c|c|c|c|c|c|c|c|}
\hline \multirow[b]{3}{*}{ Category } & \multicolumn{6}{|c|}{ Activity intensity levels of total sample } & \multicolumn{7}{|c|}{ Boys' activity intensity levels } & \multicolumn{6}{|c|}{ Girls' activity intensity levels } \\
\hline & \multicolumn{2}{|c|}{ Sedentary } & \multicolumn{2}{|c|}{ Light } & \multicolumn{2}{|c|}{ MVPA } & \multirow[b]{2}{*}{$p$-value } & \multicolumn{2}{|c|}{ Sedentary } & \multicolumn{2}{|c|}{ Light } & \multicolumn{2}{|c|}{ MVPA } & \multicolumn{2}{|c|}{ Sedentary } & \multicolumn{2}{|c|}{ Light } & \multicolumn{2}{|c|}{ MVPA } \\
\hline & Count & $\%$ & Count & $\%$ & Count & $\%$ & & Count & $\%$ & Count & $\%$ & Count & $\%$ & Count & $\%$ & Count & $\%$ & Count & $\%$ \\
\hline \multicolumn{20}{|l|}{ Location } \\
\hline inside & 5008 & 73.1 & 1483 & 21.6 & 364 & 5.3 & & 2398 & 70.3 & 797 & 23.4 & 212 & 6.2 & 2615 & 75.7 & 686 & 19.9 & 152 & 4.4 \\
\hline outside & 2914 & 45.2 & 2318 & 36.0 & 1215 & 18.8 & $<0.001$ & 1196 & 38.5 & 1193 & 38.4 & 720 & 23.2 & 1718 & 51.5 & 1125 & 33.7 & 495 & 14.8 \\
\hline \multirow{2}{*}{\multicolumn{20}{|c|}{$\begin{array}{l}\text { Group } \\
\text { composition }\end{array}$}} \\
\hline & & & & & & & & & & & & & & & & & & & \\
\hline solitary & 1409 & 57.0 & 753 & 30.5 & 308 & 12.5 & & 704 & 54.7 & 392 & 30.5 & 190 & 14.8 & 705 & 59.5 & 361 & 30.5 & 118 & 10.0 \\
\hline non-solitary & 6513 & 60.1 & 3048 & 28.1 & 1271 & 11.7 & 0.018 & 2885 & 55.2 & 1598 & 30.6 & 742 & 14.2 & 3628 & 64.7 & 1450 & 25.9 & 529 & 9.4 \\
\hline
\end{tabular}

Note: Sedentary = physical activity intensity levels 1 and 2; light = physical activity intensity level 3; MVPA = moderate-to-vigorous physical activity; corresponds to intensity levels 4 and 5; p-values of Pearson Chi-Square Tests to compare percentages spent in sedentary, light and MVPA levels across different locations and different group composition. 
Table 4. Incidence rate ratios (ICC) of total motor skill score (0-6 points) and 95\% confidence interval $(95 \% \mathrm{CI})$ by determinants assessed using Poisson regression.

\begin{tabular}{lccc}
\hline & \multicolumn{2}{l}{ Incidence in total motor skill score (0-6 points) } \\
Determinant & IRR & $\mathbf{( 9 5 \%} \mathbf{C I})$ & $\boldsymbol{p}$-value \\
\hline Constant & 0.75 & $(0.00,155.36)$ & 0.909 \\
Gender as boy & 1.18 & $(0.79,1.75)$ & 0.417 \\
Age in months & 1.03 & $(0.99,1.08)$ & 0.166 \\
Body mass index & 0.90 & $(0.79,1.75)$ & 0.131 \\
Inside physical activity intensity & 2.01 & $(0.90,4.48)$ & 0.088 \\
Outside physical activity intensity & 1.88 & $(0.95,3.74)$ & 0.070 \\
Solitary activities & 0.77 & $(0.22,2.73)$ & 0.681 \\
Sitting, squatting, kneeling & 0.32 & $(0.04,2.50)$ & 0.277 \\
\hline
\end{tabular}

